Volume 3 Nomor 1, Januari-Juni 2019: hlm. 11-18.

Magister Ilmu Hukum, Fakultas Hukum, Universitas Lampung,

Bandar Lampung, Lampung, Indonesia.

E-ISSN: 2598-3105 P-ISSN: 2723-2581

http://jurnal.fh.unila.ac.id/index.php/cepalo

(․) (1) C CEPALO

\title{
PERLINDUNGAN TERHADAP WARTAWAN PERANG DI DAERAH KONFLIK BERSENJATA MENURUT HUKUM INTERNASIONAL (STUDI KASUS DAERAH KONFLIK IRAK DAN SURIAH)
}

\author{
PROTECTION OF WAR REPORTERS IN ARMED CONFLICT AREAS BASED ON \\ INTERNATIONAL LAW (CASE STUDY OF THE IRAQ AND SYRIA CONFLICT)
}

\author{
Desia Rakhma Banjarani \\ Magister Ilmu Hukum Universitas Lampung \\ desiarahma7@gmail.com \\ Sri Sulastuti \\ Fakultas Hukum, Universitas Lampung \\ tutiunila@yahoo.co.id \\ Kisti Artiasha \\ Fakultas Hukum, Universitas Lampung \\ kisti_artiasha@yahoo.com
}

\begin{abstract}
Abstrak
Pekerjaan wartawan di daerah konflik untuk menyampaikan fakta peperangan secara obyektif kerap kali mengancam nyawa. Dalam beberapa perjanjian internasional telah termuat ketentuan tentang perlindungan terhadap wartawan yang bertugas di daerah konflik, namun terdapat beberapa hambatan untuk menegakkan ketentuan perjanjian internasional tersebut. Persoalan yang akan dibahas dalam penelitian ini adalah bagaimana perlindungan terhadap wartawan pada konflik bersenjata berdasarkan pada perjanjian internasional dalam hukum humaniter? Dan bagaimana pertanggungjawaban pidana bagi pelaku yang melanggar hukum humaniter (perang) dengan cara "membunuh-menganiaya" wartawan perang? Penelitian ini menggunakan pendekatan masalah hukum normatif (penelitian hukum kepustakaan) dengan tipe penelitian deskriptif analitis. Data yang diperoleh adalah data sekunder yang berasal dari sumber kepustakaan seperti literatur, artikel dan situs-situs internet. Hasil penelitian menunjukkan bahwa perlindungan terhadap wartawan yang bertugas saat konflik dalam hukum internasional diatur dalam Konvensi Den Haag 1907, Konvensi Jenewa 1949, Protokol Tambahan I Konvensi Jenewa 1977, dan Statuta Roma. Dalam rangka pertanggungjawaban pidana bagi pelaku pelanggaran HAM terhadap wartawan dalam hal ini yaitu ISIS, terdapat hambatan yurisdiksi yang diatur dalam Statuta Roma. Meskipun demikian, masih terdapat peluang pertanggungjawaban pidana atas pelanggaran HAM yang dilakukan ISIS terhadap wartawan, yaitu adanya tindakan dan langkah khusus dari Dewan Keamanan PBB.
\end{abstract}

Kata Kunci: Perjanjian, Wartawan, Perang.

Abstract
The work of journalists in conflict zones to convey the facts of war objectively is often life-threatening.
In several international treaties, provisions regarding the protection of journalists working in conflict areas
have been included, but there are some obstacles to enforcing the provisions of these international
agreements. The issue to be discussed in this research is how is the protection of journalists in armed
conflict based on international treaties in humanitarian law? And what about criminal liability for offenders
who violate humanitarian law (war) by "killing - persecuting" war journalists?.
This study uses a normative legal problem approach (library law research) with a descriptive
analytical type of research. The data obtained are secondary data from sources such as literature, articles
and internet sites. The results showed that the protection of journalists who served during conflicts in 
international law was regulated in the 1907 Hague Convention, 1949 Geneva Convention, Additional Protocol I of the 1977 Geneva Convention, and the Rome Statute. In the context of criminal responsibility for perpetrators of human rights violations against journalists in this case, ISIS, there are jurisdictional obstacles set out in the Rome Statute. Nevertheless, there are still opportunities for criminal liability for human rights violations committed by ISIS against journalists, namely the existence of specific actions and steps from the UN Security Council.

Keywords: Agreement, Reporters, War.

Cara Mengutip (How to Cite): Desia Rakhma Banjarani, Sri Sulastuti, Kisti Artiasha, "Perlindungan Terhadap Wartawan Perang di Daerah Konflik Bersenjata Menurut Hukum Internasional (Studi Kasus Daerah Konflik Irak dan Suriah)”, Jurnal Cepalo, 3 (1), (2019): 11-18.

\section{A. Pendahuluan}

Keberadaan wartawan ${ }^{1}$ saat ini memiliki peran penting dalam memenuhi hak masyarakat untuk mengetahui dan menegaskan hak asasi manusia, mengembangkan pendapat umum berdasarkan informasi yang tepat, akurat,dan seimbang. ${ }^{2}$ Untuk mendapatkan informasi yang tepat dan akurat, wartawan kerap kali diharuskan untuk terjun langsung ke lapangan untuk mengungkap fakta dan peristiwa secara langsung. Sehingga dibutuhkan seorang wartawan yang berani bertindak dalam menghadapi resiko-resiko besar yang mungkin saja akan mengancam jiwanya. Begitu pula terhadap wartawan perang yang berada atau ikut serta dalam medan pertempuran yang nantinya mungkin akan menemui berbagai rintangan yang tidak diduga sama sekali. ${ }^{3}$

Dengan adanya kemajuan teknologi informasi di era saat ini, semua orang dianggap selalu butuh informasi setiap saat dari berbagai sudut di dunia. Oleh karena itu, setiap negara di dunia seolah berlombalomba untuk memberitakan berbagai hal yang terjadi, baik secara regional, nasional maupun internasional, termasuk pemberitaan tentang terjadinya suatu konflik dan perang. Setiap terjadinya suatu konflik, beberapa negara di dunia akan mengirim para wartawan pilihan mereka ke daerah konflik tersebut untuk memberikan informasi yang berkualitas berdasarkan fakta-fakta obyektif dengan kualitas berita yang lebih menarik dan lebih cepat untuk dapat disampaikan kepada masyarakat maka wartawan diperlukan terjun langsung ke daerah konflik tersebut.

Berita dan artikel dalam peperangan yang ditulis oleh wartawan berisi tentang perincian menit dan peristiwa yang terjadi dalam peperangan seperti lokasi geografis di mana mereka berada yang menggambarkan tentang penderitaan setiap tentara yang gugur dalam peperangan dan kematian orang-orang yang tidak bersalah. ${ }^{4}$ Dengan kata lain, wartawan dalam peperangan telah menjadi mata dan telinga bagi masyarakat di seluruh dunia. Peran wartawan yang melaksanakan tugasnya di daerah konflik bukanlah tanpa adanya resiko, bukan rahasia umum bila pekerjaan di daerah konflik seperti pekerjaan wartawan akan mengancam nyawa dan jiwa mereka. Bahkan kerap kali wartawan yang sedang bekerja di daerah konflik harus mengalami berbagai pelanggaran HAM (hak asasi manusia) seperti luka-luka, menjadi tawanan perang, bahkan meninggal dunia di daerah konflik.

Salah satu daerah konflik yang memakan banyak korban adalah Suriah dan Irak, dimana sebagian besar konflik di daerah tersebut didalangi oleh pasukan (Islamic State of Irak and Syiria) atau ISIS. ${ }^{5}$ Beberapa korban dari serangan ISIS diantaranya adalah wartawan, bahkan berdasarkan laporan Federasi Wartawan Internasional tahun 2016, Irak adalah negara paling mematikan di dunia bagi wartawan - dengan lebih dari

\footnotetext{
${ }^{1}$ Wartawan merupakan profesi untuk memperoleh informasi dengan mendatangi sumbernya. Istilah yang di gunakan adalah meliput. Hasil liputan tersebut akan wartawan tulis, kemudian di serahkan redaktur kemudian di olah lagi dan di sajikan dalam bentuk tulisan di media cetak, radio, atau televisi. Sulistiono, Senangnya Menjadi Wartawan, Yogyakarta: Citra Aji Prama, (2012), hlm.2.

${ }^{2}$ Ibid.

3 Zurriati, "Perlindungan Terhadap Wartawan Perang Ditinjau Dari Hukum Humaniter Internasional (Suatu Tinjauan Terhadap Pelaksanaan Konvensi Jenewa 1949 Mengenai Perlindungan Bagi Wartawan Perang Dalam Meliput Konflik Timor Timur)", Tesis Universitas Andalas, Fakultas Hukum, hlm. 1.

${ }^{4}$ Vishnu Prabhu K.S dan Dr. Laxmi Dhar Dwivedi, “Journalists' Reporting Efforts, Techniques and Trends during War and Crisis Scenarios", Global Media Journal, Vol 13, Issue 24, hlm.2.

${ }^{5}$ ISIS (Islamic State of Irak and Syiria) atau Negara Islam Irak dan Syiria adalah gerakan keagamaan yang berupaya untuk menegakkan pemerintahan atau negara yang berlandaskan sistem islam (Khilafah Islamiyah) yaitu kelompok ekstremis yang mengikuti ideologi garis keras Al-Qaidah dan berpedoman kepada prinsip-prinsip jihad global. Devi Aryani, "Fenomena Radikalisme Gerakan Isis di Indonesia”, Jurnal Universitas Muhammadiyah Surakarta, (2015), hlm.10.
} 
300 wartawan tewas sejak tahun 1990 hingga $2015 .{ }^{6}$ Salah satunya wartawan asal Jepang bernama Kenji Goto yang dipenggal kepalanya pada Januari 2015. Lalu di tahun 2014, ISIS juga mengeksekusi mati James Foley dan Steven Sotloff, wartawan asal Amerika Serikat. ${ }^{7}$ Adapun wartawan perempuan bernama Ruqia Hassan yang diculik lalu dieksekusi mati oleh ISIS pada tahun $2016 .{ }^{8}$

Setelah mengungkapkan pentingnya keberadaan wartawan di daerah konflik namun keberadaan wartawan di daerah konflik justru beresiko tinggi dan mengancam nyawa bahkan mengalami pelanggaran HAM, maka dapat terlihat bahwa diperlukan adanya perlindungan bagi wartawan yang melaksanakan tugasnya di daerah konflik. Kesadaran tentang pentingnya perlindungan keberadaan wartawan dalam daerah konflik bukan merupakan isu baru, dimana pembahasan tentang isu ini sudah berlangsung cukup lama yaitu sejak era Perang Dunia terbukti dengan terbentuknya berbagai bentuk dari perjanjian internasional yang memuat tentang perlindungan kepada wartawan.

Perjanjian internasional tentang perlindungan terhadap wartawan termuat dalam hukum humaniter atau hukum perang yang berisi sekumpulan aturan tentang tata cara berperang dan perlindungan terhadap korban perang. ${ }^{9}$ Bila wartawan berada dalam suatu wilayah yang sedang berperang atau berkonflik maka dapat dipastikan bahwa wartawan berada dalam perlindungan hukum humaniter. Perlindungan wartawan dalam hukum humaniter termuat dalam berbagai perjanjian internasional yang disebut sebagai konvensi, seperti Konvensi IV Den Haag 1907 tentang Penghormatan Hukum-hukum Perang serta Kebiasaan Perang di Darat (Respecting the Laws and Customs of War on Land) dan Konvensi Jenewa III 1949 serta Protokol Tambahan I 1977. Dengan adanya hukum yang memberikan perlindungan terhadap wartawan maka tindakan ISIS yang melanggar HAM para wartawan dengan menculik dan membunuh mereka merupakan tindakan yang melanggar hukum humaniter.

Pelanggaran dalam hukum humaniter atau disebut sebagai kejahatan perang merupakan kejahatan internasional yang menjadi yurisdiksi materil dari Mahkamah Pidana Internasional atau International Criminal Court (ICC). ICC adalah pengadilan tetap dan independen yang dibentuk untuk melakukan penyelidikan dan mengadili setiap orang yang melakukan pelanggaran terberat terhadap hukum humaniter internasional, seperti kejahatan perang, kejahatan kemanusiaan, genosida dan tindakan agresi. ${ }^{10}$ Atas tindakan-tindakan keji ISIS terhadap wartawan yang melanggar hukum humaniter, dapat dikatakan sudah seharusnya ICC sebagai pengadilan permanen untuk menghukum ISIS. Namun untuk memberikan hukuman kepada ISIS atas tindakannya yang melanggar hukum humaniter bukanlah perkara yang mudah.

Hal tersebut berkaitan dengan adanya yurisdiksi ${ }^{11}$ yang membatasi kinerja ICC untuk menuntut ISIS, yakni yurisdiksi teritorial. ${ }^{12}$ Berdasarkan Statuta Roma, ICC dapat menjalankan yurisdiksinya atas siapapun (baik warga dari negara pihak Statuta Roma 1998 ataupun bukan warga) sepanjang kejahatan dilakukan di wilayah Negara Pihak Statuta Roma 1998 dan ICC juga dapat menjalankan kewenangannya terhadap kejahatan internasional di wilayah negara manapun (baik wilayah Negara Pihak Statuta Roma 1998 ataupun bukan negara pihak) sepajang pelakunya adalah warga dari Negara Pihak. ${ }^{13}$ Dalam hal ini kejahatan yang dilakukan ISIS berkisar diwilayah Irak dan Suriah dimana kedua negara tersebut belum meratifikasi Statuta Roma sehingga membuat ICC tidak memiliki yurisdiksi atas kedua negara tersebut. Meskipun demikian, bukan berarti menjadi ketidakmungkinan bagi ICC untuk menuntut ISIS berdasarkan Statuta Roma.

Berdasarkan latar belakang tersebut di atas, maka persoalan yang akan dibahas dalam penelitian ini adalah bagaimana perlindungan terhadap wartawan pada konflik bersenjata berdasarkan pada perjanjian internasional dalam hukum humaniter? Dan bagaimana pertanggungjawaban pidana dari pelaku yang

\footnotetext{
${ }^{6}$ Human Right Watch, “Iraq”, Coutry Summary, January 2017, hlm. 4.

${ }^{7}$ https://m.tempo.co/read/news/2015/06/25/115678140/korban-kekejian-isis-dari-wartawan-hingga-penderita-aids, diakses pada 25 Agustus 2017, jam 16:15 WIB.

${ }^{8}$ http://global.liputan6.com/read/2405247/kisah-ruqia-hassan-jurnalis-cantik-yang-dieksekusi-mati-isis, diakses pada 25 Agustus 2017, jam 16:19 WIB.

${ }_{9}^{9}$ Adnan Buyung Nasution dan Patra M. Zen, Instrumen Internasional Pokok Hak Asasi Manusia, Jakarta: Yayasan Obor Indonesia, (2006), hlm. 4.

${ }^{10}$ Koalisi Masyarakat Sipil untuk Mahkamah Pidana Internasional, Mengenal ICC (Mahkamah Pidana Internasional), Jakarta: IKOHI, (2009), hlm. 9.

${ }^{11}$ Yurisdiksi dalam pengertian hukum berarti hak/kekuasaan/kewenangan suatu negara untuk membuat, mengatur dan menegakkan aturan terhadap orang, benda, dan peristiwa-peristiwa yang terjadi dalam batas teritorialnya. Abdul Muthalib Tahar, Hukum Internasional dan Perkembangannya, Bandar Lampung: PKKPUU Unila, (2013), hlm. 92.

${ }^{12}$ Yurisdiksi terhadap semua orang dan benda di dalam batas-batas teritorialnya dan dalam semua perkara perdata dan pidana yang timbul di dalam batas-batas teritorial ini. J. G. Starke, Pengantar Hukum Internasional Edisi Kesepuluh, Jakarta: Sinar Grafika, (2010), hlm.270.

${ }^{13}$ Pasal 12 dan 13 Statuta Roma.
} 
melanggar hukum humaniter (perang) dengan cara "membunuh-menganiaya" wartawan perang? Penelitian ini menggunakan pendekatan masalah hukum normatif (penelitian hukum kepustakaan) dengan tipe penelitian deskriptif analitis. Data yang diperoleh adalah data sekunder yang berasal dari sumber kepustakaan seperti literatur, artikel dan situs-situs internet.

\section{B. Pembahasan}

\section{Perlindungan Terhadap Wartawan Perang Menurut Hukum Internasional}

Salah satu sumber hukum internasional adalah perjanjian yang berisikan instrumen yuridis yang menampung kehendak dan persetujuan negara atau subjek hukum internasional lainnya untuk mencapai tujuan bersama, yang mana pembuatannya diatur oleh hukum internasional dan menimbulkan akibat hukum yang mengikat bagi para pihak yang membuatnya. ${ }^{14}$ Perjanjian dalam hukum internasional dapat mencangkup berbagai aspek seperti ekonomi, sosial, budaya, bahkan hingga peperangan. Menurut hukum internasional, perjanjian tentang peperangan ${ }^{15}$ disebut sebagai hukum humaniter yang didalamnya juga mengatur tentang perlindungan wartawan dalam daerah konflik bersenjata.

Secara umum perjanjian internasional yang mengatur tentang perlindungan terhadap wartawan di daerah konflik termuat dalam konvensi. Konvensi merupakan suatu instrumen yang biasanya digunakan dalam perjanjian-perjanjian multilateral baik terbatas maupun terbuka yang mengatur hal-hal yang dianggap sangat penting, dan biasanya hal-hal tersebut bukan hal yang sederhana dan diatur secara mendetail. ${ }^{16}$ Dalam hal ini konvensi yang mengatur tentang perlindungan wartawan di daerah konflik termuat dalam hukum humaniter. Tujuan dari Hukum Humaniter adalah untuk memberikan perlindungan kepada mereka yang menderita atau yang menjadi korban dari perang, baik mereka yang secara nyata dan aktif dalam pertikaian (kombat), maupun mereka yang tidak turut serta dalam pertikaian (penduduk sipil). ${ }^{17}$

Selain itu, hukum humaniter hanya berlaku saat suatu konflik bersenjata terjadi dan untuk mengidentifikasi keberlakuan hukum humaniter maka harus dibedakan antara konflik bersenjata internasional dan konflik bersenjata non-internasional. ${ }^{18}$ Tidak hanya mengatur tentang tata cara berperang yang dimuat dalam hukum Den Haag, ${ }^{19}$ tetapi hukum humaniter internasional juga memberi perlindungan terhadap korban dari perang tersebut yang termuat dalam hukum jenewa. ${ }^{20}$

Pada hukum den haag perlindungan terhadap wartawan diatur dalam Konvensi IV Den Haag 1907 tentang Penghormatan Hukum-hukum Perang serta Kebiasaan Perang di Darat (Respecting the Laws and Customs of War on Land) Pasal 13 yang menyatakan: ${ }^{21}$

"Individuals who follow an army without directly belonging to it such as newspaper correspondents and reporters, sulters and contractors, who fall into enemy's hands and whom the latter thinks fit to detain, are entiteld to be treated as prisoners of war, provided they are in possesion of certificate from the military authorities of the army which they are accompanying".

Berdasarkan pasal tersebut dapat disimpulkan bahwa seorang jurnalis (dengan istilah: news paper correspondent and reporters), yang jatuh ke tangan salah satu pihak berperang dan ditahan oleh salah satu pihak berperang tersebut maka ia diperlakukan (treated)sebagai tawanan perang namun jurnalis tersebut juga dapat tidak dianggap sebagai tawanan perang. Untuk memenuhi syarat diperlakukan sebagai tawanan perang,

\footnotetext{
${ }^{14}$ Boer Mauna, Hukum Internasional: Pengertian, Peranan, dan Fungsi dalam Era Dinamika Global, Bandung: Alumni, (2008), hlm. 82 .

${ }^{15}$ Perang adalah konflik antar satu negara dengan negara lain negara untuk kontrol politik atas orang, wilayah, atau sumber daya. Eric J. Schnitzer, Lieutenant Colonel, USAF, Perfecting War: Searching for the Silver Bullet, Alabama: Maxwell AFB, (2005), hlm.275.

${ }^{16}$ F.A. Whisnu Situni, Identifikasi dan Reformulasi Sumber-Sumber Hukum Internasional, Bandung: Mandar Maju, (1989), hlm. 10.

${ }^{17}$ Haryomataram, Pengantar Hukum Humaniter, Jakarta: Raja Grafindo, (2005), hlm 3.

${ }^{18}$ Roberta Arnold, International Humanitarian Law dan Human Rights Law, Boston: Martinus Nijhoff Publisher, (2008), hlm.357.

${ }^{19}$ Hukum Den Haag (The Hague Laws) merupakan sumber hukum humaniter tertulis yang memiliki fokus pengaturan terhadap tata cara peperangan serta jenis persenjataan yang diperkenankan untuk dipakai selama masa perang.Hukum Den Haag lebih terkait dengan peraturan mengenai cara dan sarana bertempur dan memusatkan perhatiannya pada tindakan operasi militer. C. De Rover, To Serve and To Protect Acuan Universal Penegakan HAM, Jakarta: Raja Grafindo Persada, (2000), hlm. 100.

${ }^{20}$ Hukum Jenewa atau dalam bahasa inggris disebut The Geneva Laws yaitu hukum yang mengatur mengenai perlindungan terhadap kombatan dan penduduk sipil dari akibat perang. Secara umum hukum jenewa merujuk pada sekelompok norma Hukum Humaniter Internasional yang lebih terfokus pada kondisi korban perang. Harry Purwanto, "Hukum Humaniter Internasional dan Hukum Hak Asasi Manusia", Mimbar Hukum, Vol. 18, No. 2, (2006), hlm 189

${ }^{21}$ Convention (IV) 1907 respecting the Laws and Customs of War on Land and its annex: Regulations concerning the Laws and Customs of War on Land.
} 
para jurnalis harus memiliki sertifikat yang dikeluarkan oleh pimpinan angkatan bersenjata yang mereka ikuti, dengan adanya sertifikat tersebut jika seorang jurnalis ditahan oleh pihak berperang maka jurnalis itu diperlakukan sebagai tawanan perang, sebaliknya jika jurnalis tidak memiliki sertifikat dari salah satu pasukan bersenjata maka bila jurnalis ditahan, maka jurnalis itu dapat diperlakukan tidak seperti tawanan perang.

Untuk menegaskan kembali perlindungan terhadap wartawan yang terdapat dalam hukum den haag, maka hukum jenewa sebagai hukum yang melindungi korban perang kembali menyebutkan perlindungan terhadap wartawan dalam Pasal 4 Konvensi III Jenewa 1949 tentang Perlakuan terhadap Tawanan Perang telah ditentukan golongan-golongan yang dianggap sebagai tawanan perang, dimana jurnalis termasuk dalam golongan ke-empat. Pasal 4 bagian A (4) dimana dinyatakan: ${ }^{22}$

"Persons who accompany the armed forces without actually being members thereof, such as civilian members of military aircraft crews, war correspondents, supply contractors, members of labour units or of services responsible for the welfare of the armed forces, provided that they have received authorization, from the armed forces which they accompany, who shall provide them for that purpose with an identity card similar to the annexed model".

Berdasarkan pasal tersebut dapat terlihat bahwa tidak terdapat banyak perbedaan dengan Pasal 13 Konvensi IV Den Haag 1907 yang telah disebutkan sebelumnya, yakni keberadaan wartawan dalam konflik bersenjata masih diberikan syarat dengan adanya kartu identitas yang dikeluarkan oleh salah pihak berperang. Namun adapun terdapat perbedaan, dimana pada Pasal 13 Konvensi IV Den Haag 1907 istilah untuk wartawan adalah news corespondents and reporters, sedangkan dalam Pasal 4 Konvensi III Jenewa 1949, istilah wartawan berubah menjadi war correspondents.

Selain itu, penegasan tentang perlindungan wartawan juga diatur dalam Protokol Tambahan I Konvensi Jenewa $1977^{23}$ yang mengatur tentang perlindungan korban pada perang internasional. Dalam Protokol Tambahan I perlindungan wartawan diatur secara tegas dalam sub bagian III Pasal 79 ayat (1), (2), (3). Pada ayat (1) menyebutkan bahwa status wartawan dalam konflik bersenjata harus dianggap sebagai warga sipil, sedangkan dalam ayat (2) menjelaskan bahwa wartawan akan dilindungi di bawah konvensi jenewa dan protokol ini, asalkan mereka tidak mengambil tindakan yang dapat mempengaruhi dan memberi kerugian pada orang-orang sipil, dan tanpa mengurangi hak sipil sebagai wartawan perang yang ditugaskan pada angkatan perang. Adapun dalam ayat (3) menjelaskan tentang syarat wartawan agar dapat bertugas dalam konflik bersenjata yaitu wartawan harus memiliki kartu tanda pengenal wartawan yang dikeluarkan oleh pemerintah negara dari mana wartawan itu merupakan warganegaranya atau negara wartawan itu bertempat tinggal atau dimana kantor pemberitaan yang mempekerjakannya berada. ${ }^{24}$

\section{Pertanggungjawaban Pidana Bagi Pelaku yang Melanggar Hukum Humaniter (Perang) terhadap Wartawan Perang}

Berdasarkan pemaparan di atas dapat terlihat dengan jelas bahwasannya wartawan dalam konflik bersenjata dilindungi oleh hukum humaniter. Namun dengan adanya peraturan tersebut tidak menutup kemungkinan dapat menjadikan wartawan sebagai korban dari konflik bersenjata. Hal tersebut dapat terlihat pada konflik di Irak dan Suriah yang didalangi oleh Islamic State of Irak and Syiria atau ISIS. Pada konflik tersebut telah banyak memakan korban jiwa, korban-korban tersebut salah satunya adalah wartawan. Sejak 2011 ISIS kerap kali melakukan penyerangan terhadap wartawan laki-laki maupun perempuan yang berasal dari beberapa negara, bahkan dilaporkan sejak tahun 2011 ISIS telah mengeksekusi mati 17 wartawan dan menculik 80 wartawan. ${ }^{25}$ Bahkan saat para wartawan tersebut diculik, ISIS kerap kali melakukan tindakan

\footnotetext{
${ }^{22}$ Geneva Convention (III) on Prisoners of War, 1949 and its commentary

${ }^{23}$ Protokol Tambahan I merupakan pelengkap dari Konvensi Jenewa 1949 yang terdiri dari Protokol Tambahan I dan Protokol Tambahan II, meskipun hanya bersifat pelengkap Protokol Tambahan I menjelaskan secara signifikan tentang perlindungan bagi korban-korban perang seperti warga sipil yang terluka maupun tewas. https://www.icrc.org/eng/resources/documents/misc/additional-protocols-1977.htm, diakses pada 10 September 2016, jam 20:11 WIB

${ }^{24}$ Direktorat Jenderal Administrasi Hukum Umum Departemen Kehakiman Dan Hak Asasi Manusia Republik Indonesia, Protokol Tambahan Pada Konvensi-Konvensi Jenewa 12 Agustus 1949 Dan Yang Berhubungan Dengan Perlindungan Korban-Korban Pertikaian-Pertikaian Bersenjata Internasional (Protokol I) dan Bukan Internasional (Protokol II), Jakarta: Direktorat Jenderal Administrasi Hukum Umum Departemen Kehakiman Dan Hak Asasi Manusia Republik Indonesia, (2003), hlm. 110.

${ }^{25} \mathrm{https}: / / \mathrm{m}$. tempo.co/read/news/2015/06/25/115678140/korban-kekejian-isis-dari-wartawan-hingga-penderita-aids, diakses pada 25 Agustus 2017, jam 16:15 WIB.
} 
kekerasan dan pelanggaran hak asasi manusia hingga berakhir dengan eksekusi mati pada wartawanwartawan tersebut.

Sebagaimana yang telah disebutkan sebelumnya bahwa wartawan dalam konflik bersenjata dilindungi oleh hukum humaniter, bahkan apabila wartawan telah tertangkap oleh musuh dalam konflik bersenjata maka ia harus dilindungi sebagai masyarakat sipil, apabila memenuhi syarat tertentu maka wartawan akan ditetapkan sebagai tawanan perang yang memiliki hak-hak untuk dilindungi ${ }^{26}$ Namun apa yang terjadi pada wartawan saat konflik bersenjata di Irak dan Suriah yang dilakukan oleh ISIS telah melanggar ketentuan dalam hukum humaniter. Sehingga ISIS sebagai tersangka utamanya harus diadili atas kejahatan perang yang telah ia perbuat. Satu-satunya pengadilan permanen di dunia yang memiliki yurisdiksi untuk menghukum pelaku kejahatan perang yang melanggar hukum humaniter adalah Mahkamah Pidana Internasional atau ICC. Dengan kata lain, ISIS dapat diadili oleh ICC atas kejahatan yang mereka perbuat.

Namun untuk memberikan hukuman kepada ISIS atas tindakannya yang melanggar hukum humaniter bukanlah perkara yang mudah. Hal tersebut berkaitan dengan adanya yurisdiksi ICC yang membatasi kinerja ICC untuk menuntut ISIS, yakni yurisdiksi teritorial. Hal ini didasarkan pada ketentuan yang termuat dalam perjanjian internasional yang menjadi tonggak kerja ICC yaitu Statuta Roma. ${ }^{27}$ Statuta sendiri merupakan salah satu bentuk dari perjanjian internasional yang digunakan sebagai instrumen dari perjanjian yang akan membentuk dan melandasi suatu organisasi internasional. ${ }^{28}$

Berdasarkan Statuta Roma, ICC dapat menjalankan yurisdiksinya atas siapapun (baik warga dari negara pihak Statuta Roma 1998 ataupun bukan warga) sepanjang kejahatan dilakukan di wilayah Negara Pihak Statuta Roma 1998 dan ICC juga dapat menjalankan kewenangannya terhadap kejahatan internasional di wilayah negara manapun (baik wilayah Negara Pihak Statuta Roma 1998 ataupun bukan negara pihak) sepajang pelakunya adalah warga dari Negara Pihak. Dalam hal ini kejahatan yang dilakukan ISIS berkisar diwilayah Irak dan Suriah dimana kedua negara tersebut belum meratifikasi Statuta Roma sehingga membuat ICC tidak memiliki yurisdiksi atas kedua negara tersebut. Dengan tidak adanya yurisdiksi ICC pada Irak dan Suriah maka ISIS tidak dapat dilaporkan kepada ICC dan ICC tidak dapat begitu saja mengadili ISIS tanpa adanya yurisdiksi. Meskipun demikian, bukan berarti tidak ada cara bagi dunia untuk mengadili ISIS atas segala bentuk kehajatan yang mereka perbuat. Karena bagaimanapun, tujuan dibentuknya ICC adalah untuk meningkatkan keadilan distributif sehingga akan tidak adil jika ISIS tidak dapat diadili mengingat korban ISIS yang tidak sedikit. ${ }^{29}$

Berdasarkan ketentuan Statuta Roma 1998, ICC memang tidak memiliki yurisdiksi bagi pelaku kejahatan bukan warga negara dari negara pihak ratifikasi Statuta Roma, dan kejahatan yang tidak dilakukan di negara pihak. Namun jika kejahatan internasional dilakukan oleh bukan warga negara dari negara pihak ratifikasi Statuta Roma, dan kejahatan yang tidak dilakukan di negara pihak maka ICC tetap dapat mengadili pelaku kejahatan tersebut berdasarkan rujukan Dewan Keamanan $\mathrm{PBB},{ }^{30}$ sebagai badan yang memiliki kewajiban untuk menjaga perdamaian dan keamanan dunia. ${ }^{31}$ Sehingga ICC dapat mengadili dan menghukum ISIS namun berdasarkan rekomendasi dari Dewan Keamanan PBB. Namun hingga saat ini Penuntut Umum ICC belum juga melakukan penyelidikan terhadap ISIS atas berbagai tindak kejahatan yang mereka perbuat, sehingga dapat dikatakan Dewan Keamanan belum mengajukan usulan terhadap Penuntut Umum ICC untuk menyelidiki ISIS.

Namun bukan berarti Dewan Keamanan diam saja atas kejahatan yang dilakukan oleh ISIS, dalam hal ini Dewan Keamanan telah mengeluarkan beberapa resolusi terkait atas berbagai kejahatan yang diperbuat oleh ISIS, seperti pada 16 Desember 2015 Dewan Kemanan mengeluarkan resolusi S/PRST/2015/25 tentang penyelidikan perdagangan orang, wanita dan anak-anak yang dilakukan oleh ISIS. Kemudian pada 24

\footnotetext{
${ }^{26}$ Pasal 45 dan Pasal 79 Bagian II Protokol Tambahan I 1977 Konvensi Jenewa.

27 Statuta Roma adalah perjanjian internasional yang melandasi pendirian Pengadilan Pidana Internasional (ICC) yang dibentuk berdasarkan Konferensi Internasional di Roma pada tahun 1998. Dengan tujuan melaksanakan yurisdiksinya pada kejahatan yang paling serius dalam pelanggaran hukum hak asasi manusia internasional dan humaniter. Coalition for the International Criminal Court (CICC), Core Crimes Defined in the Rome Statute of the International Criminal Court, New York: Sally Eberhardt, Media Liaison, (2017), hlm. 1.

${ }^{28}$ F.A. Whisnu Situni, Op.Cit., hlm.48.

${ }^{29}$ Heni Siswanto, Hukum Pidana Internasional Teori dan Praktik, Bandar Lampung: Aura, (2016), hlm.31.

${ }^{30}$ Dewan Keamanan adalah badan utama dari PBB yang terdiri dari Amerika Serikat, Inggris, Prancis, Uni Soviet, dan Cina sebagai anggota tetap Dewan Keamanan. Dewan Keamanan memiliki tugas khusus dalam bidang perdamaian dan keamanan internasional dimana lima negara ini memiliki peranan dalam peperangan melawan fasisme. Sri Setianingsih Suwardi, Pengantar Hukum Organisasi Internasional, Jakarta: UI Press, 2004, hlm. 252.

${ }^{31}$ Pasal 13 Statuta Roma.
} 
APRIL 2015 Dewan Kemanan kembali mengeluarkan resolusi S/PRST/2015/10 tentang krisis kemanusiaan di Suriah. Lalu pada 2015 Dewan Kemanan mengeluarkan resolusi SC/12090 tentang saran penyelidikan terhadap dana gelap yang digunakan ISIS serta penyelidikan pada anggota ISIS. Adapun Dewan Keamanan pada akhirnya membentuk resolusi 21 Desember 2016 A/RES/71/248 untuk mendirikan suatu Mekanisme Internasional yang adil dan independen untuk membantu penyelidikan dan penuntutan mereka yang bertanggung jawab atas kejahatan paling serius di bawah hukum internasional yang dilakukan di Suriah sejak Maret 2011. Resolusi tersebut dirancang oleh Liechtenstein dan disahkan dengan 105 suara negara yang mendukung dan 15 negara menolak dan 52 negara abstain. ${ }^{32}$ Sejauh ini dapat terlihat, bahwa upaya nyata Dewan Keamanan dalam melakukan penuntutan terhadap ISIS belum membuahkan hasil nyata terkait dengan hukuman yang pantas diterima ISIS atas setiap kejahatan yang mereka lakukan.

\section{Penutup}

Perlindungan wartawan yang bertugas saat konflik diatur dalam beberapa perjanjian internasional seperti Konvensi Den Haag 1907, Konvensi Jenewa 1949, dan Protokol Tambahan I Konvensi Jenewa 1977, bahkan pelanggaran HAM terhadap wartawan juga termasuk dalam kategori kejahatan perang yang menjadi salah satu yurisdiksi materil Statuta Roma. Statuta Roma merupakan salah satu bentuk dari perjanjian internasional yang telah disepakati oleh negara-negara di dunia dan telah menjelma menjadi suatu hukum yang harus dipatuhi oleh negara-negara di dunia. Sebagai salah satu perjanjian yang telah menjadi hukum internasional, dalam hal ini Statuta Roma juga memiliki kekuatan yuridis dalam menegakkan keadilan dan menghukum setiap pelaku kejahatan tidak beradab yang terjadi di belahan dunia manapun, termasuk kejahatan perang yang dilakukan oleh ISIS. Sehingga kekuatan hukum yang dimiliki Statuta Roma tidak dapat diragukan lagi dalam rangka menghukum ISIS sebagai pelaku kejahatan perang. Atas pelanggaran HAM dilakukan ISIS terhadap wartawan, maka ISIS dapat diadili oleh ICC melalui rujukan oleh Dewan Keamanan PBB berdasarkan ketentuan yang diatur dalam Statuta Roma 1998.

\section{A. Buku}

\section{Daftar Pustaka}

Adnan Buyung Nasution dan Patra M. Zen. (2006). Instrumen Internasional Pokok Hak Asasi Manusia. Jakarta: Yayasan Obor Indonesia.

Arnold, Roberta. (2008). International Humanitarian Law dan Human Rights Law. Boston: Martinus Nijhoff Publisher.

Coalition for the International Criminal Court (CICC). (2017). Core Crimes Defined in the Rome Statute of the International Criminal Court. New York: Sally Eberhardt, Media Liaison.

Direktorat Jenderal Administrasi Hukum Umum Departemen Kehakiman Dan Hak Asasi Manusia Republik Indonesia. (2003). Protokol Tambahan Pada Konvensi-Konvensi Jenewa 12 Agustus 1949 Dan Yang Berhubungan Dengan Perlindungan Korban-Korban Pertikaian-Pertikaian Bersenjata Internasional (Protokol I) dan Bukan Internasional (Protokol II), Jakarta: Direktorat Jenderal Administrasi Hukum Umum Departemen Kehakiman Dan Hak Asasi Manusia Republik Indonesia

Eric J. Schnitzer, Lieutenant Colonel, USAF. (2005). Perfecting War: Searching for the Silver Bullet. Alabama: Maxwell AFB.

Haryomataram. (2005). Pengantar Hukum Humaniter. Jakarta: Raja Grafindo.

Koalisi Masyarakat Sipil untuk Mahkamah Pidana Internasional. (2009). Mengenal ICC (Mahkamah Pidana Internasional). Jakarta: IKOHI.

Mauna, Boer. (2008). Hukum Internasional: Pengertian, Peranan, dan Fungsi dalam Era Dinamika Global. Bandung: Alumni.

Rover, C. De. (2000). To Serve and To Protect Acuan Universal Penegakan HAM, Jakarta: Raja Grafindo Persada.

Siswanto, Heni. (2016). Hukum Pidana Internasional Teori dan Praktik. Bandar Lampung: Aura.

Situni, F.A. Whisnu. (1989). Identifikasi dan Reformulasi Sumber-Sumber Hukum Internasional. Bandung: Mandar Maju.

Starke, J. G. (2010). Pengantar Hukum Internasional Edisi Kesepuluh, Jakarta: Sinar Grafika.

Sulistiono. (2012). Senangnya Menjadi Wartawan, Yogyakarta: Citra Aji Prama.

\footnotetext{
${ }^{32}$ http://www.securitycouncilreport.org/un-documents/syria/, diakses pada 3 November 2017, jam 11:02 WIB.
} 
Tahar, Abdul Muthalib. (2013). Hukum Internasional dan Perkembangannya, Bandar Lampung: PKKPUU Unila.

\section{B. Jurnal dan Artikel}

Devi Aryani, "Fenomena Radikalisme Gerakan Isis di Indonesia", Jurnal Universitas Muhammadiyah Surakarta, (2015).

Harry Purwanto, "Hukum Humaniter Internasional dan Hukum Hak Asasi Manusia", Mimbar Hukum, Vol. 18, No. 2, (2006)

Human Right Watch, "Iraq", Coutry Summary, January 2017.

Vishnu Prabhu K.S dan Dr. Laxmi Dhar Dwivedi, “Journalists' Reporting Efforts, Techniques and Trends during War and Crisis Scenarios", Global Media Journal, Vol 13, Issue 24.

Zurriati, "Perlindungan Terhadap Wartawan Perang Ditinjau Dari Hukum Humaniter Internasional (Suatu Tinjauan Terhadap Pelaksanaan Konvensi Jenewa 1949 Mengenai Perlindungan Bagi Wartawan Perang Dalam Meliput Konflik Timor Timur)”, Tesis Universitas Andalas, Fakultas Hukum.

\section{Internet}

http://global.liputan6.com/read/2405247/kisah-ruqia-hassan-jurnalis-cantik-yang-dieksekusi-mati-isis, diakses pada 25 Agustus 2017, jam 16:19 WIB.

http://www.securitycouncilreport.org/un-documents/syria/, diakses pada 3 November 2017, jam 11:02 WIB.

https://m.tempo.co/read/news/2015/06/25/115678140/korban-kekejian-isis-dari-wartawan-hingga-penderitaaids, diakses pada 25 Agustus 2017, jam 16:15 WIB.

https://m.tempo.co/read/news/2015/06/25/115678140/korban-kekejian-isis-dari-wartawan-hingga-penderitaaids, diakses pada 25 Agustus 2017, jam 16:15 WIB.

https://www.icrc.org/eng/resources/documents/misc/additional-protocols-1977.htm, diakses pada 10 September 2016, jam 20:11 WIB.

\section{Peraturan}

Convention (IV) 1907 respecting the Laws and Customs of War on Land and its annex: Regulations concerning the Laws and Customs of War on Land.

Geneva Convention (III) on Prisoners of War, 1949 and its commentary

Protokol Tambahan I 1977 Konvensi Jenewa

Statuta Roma 